\title{
Research on the Design of Evaluation System for Coordinated Development of Beijing-Tianjin-Hebei Region
}

\author{
Dan $\mathrm{Wu}^{1, *}$ Siqi Cao ${ }^{1}$ \\ ${ }^{1}$ School of Economics and Management, North China University of Technology, Beijing 100144, China \\ *Corresponding author.Email: wu_daniel@163.com
}

\begin{abstract}
By analyzing the main factors affecting the coordinated development of the Beijing-Tianjin-Hebei region, the construction of the Beijing-Tianjin-Hebei regional coordinated development evaluation system plays an important supporting role in accelerating the progress of the coordinated development of the Beijing-Tianjin-Hebei region. Based on the overall situation of the national economic and social development of Beijing-Tianjin-Hebei region and from the dimensions of science and technology, economy, society and ecology, the paper conducts the qualitative screening of the evaluation indicators of coordinated development of Beijing-Tianjin-Hebei region by using method of policy literature review and combining the two categories of indicators of "policy orientation" and "document reference". On this basis, the principal component - correlation analysis method is used to quantitatively screen the evaluation indicators of the coordinated development of the Beijing-Tianjin-Hebei region. Then, the evaluation index system for the coordinated development of the Beijing-Tianjin-Hebei region can be determined. This evaluation index system helps to evaluate the coordinated development status of the Beijing-Tianjin-Hebei region from a comprehensive perspective, and makes up for the shortcomings of the existing results that are from a single perspective.
\end{abstract}

\section{Keywords: Beijing-Tianjin-Hebei region, coordinated development, dimensions, indicators, evaluation}

\section{INTRODUCTION}

The Beijing-Tianjin-Hebei region accounts for $2.3 \%$ of China's land area, carries $8 \%$ of China's population, and creates nearly $11 \%$ of China's total economic output. It is an important engine for promoting China's national economic and social development. The issuance and implementation of policy documents such as the "Beijing-Tianjin-Hebei Coordinated Development Plan Outline" and the "Beijing-TianjinHebei National Economic and Social Development Plan During the 13th Five-Year Plan" provide important practical guidance for the design of evaluation indicators for the coordinated development of the Beijing-Tianjin-Hebei region. The "Beijing-TianjinHebei National Economic and Social Development Plan During the 13th Five-Year Plan" clearly formulated 9 key development tasks including innovation and development, transformation and upgrading, and green development. At the same time, a number of special plans for science and technology, industry, ecological and environmental protection, transportation, and

*Fund: Youth Project of Beijing Social Science Foundation (17GLC064). education have been implemented to continuously reduce the imbalance in the development of the BeijingTianjin-Hebei region. These policies and systems have provided important policy support for accelerating the coordinated development of Beijing-Tianjin-Hebei and narrowing the development gap of Beijing-TianjinHebei. In the context of the implementation of the Beijing-Tianjin-Hebei coordinated development strategy, and based on the overall national economic and social development of the Beijing-Tianjin-Hebei region, constructing a relatively complete coordinated development evaluation system that is compatible with the economic and social development goals of the Beijing-Tianjin-Hebei region is conducive to provide theoretical guidance and decision support for the coordinated development practice of Beijing-TianjinHebei.

\section{LITERATURE REVIEW}

Since the establishment of the Beijing-TianjinHebei regional coordinated development strategy, Beijing-Tianjin-Hebei government management departments and academia have carried out a large number of practical and empirical studies. Aiming at 
the design of evaluation indicators for the coordinated development of the Beijing-Tianjin-Hebei region, technological innovation, economic development, social governance, and ecological environment have now become key factors to accelerate the development of the Beijing-Tianjin-Hebei region. Existing research focuses on the design of evaluation indicators around the dimensions of science and technology, economy, society, and ecology. Among them, the dimensions of science and technology mainly include indicators of science and technology resource stock, talent reserve, science and technology output, science and technology environment, achievement transformation, and science and technology output performance. [1-5] Economic dimensions mainly include economic scale, level, benefit, structure, quality, environment and other indicators [6-14]. Social dimensions mainly include public services, people's lives, medical education, human settlements, social structure, social welfare and other indicators [15-27]. The ecological dimensions focus on indicators such as ecological endowment, pollution status, and governance results [28-34].

To sum up, the coordinated development of the Beijing-Tianjin-Hebei region is fundamentally driven by innovation, and its physical content and key support are to accelerate the transformation and upgrading of the economy and industry. At the same time, ecological construction provides an important guarantee for the coordinated development of the Beijing-Tianjin-Hebei region. The evaluation of the coordinated development of the Beijing-Tianjin-Hebei region is a systematic evaluation conducted from the multi-dimensional perspectives of science and technology, economy, society, and ecology in the Beijing-Tianjin-Hebei region, which is beneficial to provide theoretical guidance and decision support for the coordinated development practice of the Beijing-Tianjin-Hebei region. Based on the findings of existing research literature, scholars currently have no unified standard dimension in the design of the evaluation index system for the coordinated development of the Beijing-TianjinHebei region, and they tend to construct corresponding evaluation indicators from the single-dimensional perspective of technology, economy, society, and ecology. Few scholars consider integrating science and technology, economy, society, ecology and other dimensions into a unified framework system on the basis of evaluation from single-dimensional perspective, and establish a more complete coordinated development evaluation index that is compatible with the economic and social development goals of the Beijing-Tianjin-Hebei region. Therefore, based on the overall situation of the national economic and social development of Beijing-Tianjin-Hebei, it is necessary to systematically design the evaluation index system of the coordinated development of the Beijing-TianjinHebei region from the multi-dimensional perspectives of science and technology, economy, society, ecology, etc. And then, the key constraints of the coordinated development of the Beijing-Tianjin-Hebei region can be explored to guide the coordinated development in the Beijing-Tianjin-Hebei region.

\section{RESEARCH METHODS}

\section{A. Qualitative screening methods of evaluation indicators}

The evaluation of the coordinated development of the Beijing-Tianjin-Hebei region cannot be limited to the research from the single perspective such as technological innovation, economic industry, and ecological environment. In practice, the scientific and technological, economic, social, and ecological dimensions should be integrated into a unified framework system to design the evaluation index system for the coordinated development of the BeijingTianjin-Hebei region. To this end, with reference to the "Beijing-Tianjin-Hebei Coordinated Development Plan" and the "Beijing-Tianjin-Hebei National Economic and Social Development Plan During the 13th Five-Year Plan" and other policy documents, the "policy-oriented" indicators for the development of the Beijing-Tianjin-Hebei region are defined. At the same time, referring to the core journal literature with the theme of "Beijing-Tianjin-Hebei Coordinated Development", the literature combing method is adopted to determine the "document reference" index for the coordinated development of the Beijing-TianjinHebei region. Combining the two types of indicators of "policy orientation" and "document reference", the initial indicators for the evaluation of coordinated development in the science and technology dimension (see "Table I") and economic, social and ecological dimensions (see "Table II") of Beijing-Tianjin-Hebei region can be obtained respectively. 
TABLE I. INITIAL INDICATORS OF SCIENCE AND TECHNOLOGY DIMENSIONS FOR THE EVALUATION OF COORDINATED DEVELOPMENT IN THE BEIJING-TIANJIN-HEBEI REGION

\begin{tabular}{|c|c|c|}
\hline \multirow{2}{*}{ Dimension } & \multicolumn{2}{|r|}{ Index } \\
\hline & First-level indicators & Secondary index \\
\hline \multirow{15}{*}{$\begin{array}{l}\text { Science and } \\
\text { Technology }\end{array}$} & \multirow{3}{*}{$\begin{array}{l}\text { Technological } \\
\text { investment }\end{array}$} & R\&D staff \\
\hline & & Full-time equivalent of $\mathrm{R} \& \mathrm{D}$ personnel \\
\hline & & Full-time equivalent of R\&D personnel in high-tech industry \\
\hline & \multirow{5}{*}{$\begin{array}{l}\text { Technological } \\
\text { environment }\end{array}$} & Internal expenditure of $\mathrm{R} \& \mathrm{D}$ expenses \\
\hline & & R\&D internal expenditure in high-tech industry \\
\hline & & Expenditures for new product development in high-tech industries \\
\hline & & R\&D investment intensity \\
\hline & & Local financial science and technology expenditure \\
\hline & \multirow{3}{*}{$\begin{array}{l}\text { Scientific and } \\
\text { innovation output }\end{array}$} & Number of patent applications accepted \\
\hline & & Number of granted patent applications \\
\hline & & Number of authorized invention patent applications \\
\hline & \multirow{4}{*}{$\begin{array}{l}\text { Scientific and } \\
\text { innovation effect }\end{array}$} & Number of patents per 10,000 people \\
\hline & & Technology market turnover \\
\hline & & Sales revenue of new products in high-tech industry \\
\hline & & New product export of high-tech industry \\
\hline
\end{tabular}

It can be seen from "Table I" that the technological dimension mainly includes 4 first-level indicators and 15 secondary indicators. Among them, scientific and technological innovation input includes 3 secondary indicators, scientific and technological innovation environment includes 5 secondary indicators, scientific and technological innovation output includes 3 secondary indicators, and scientific and technological innovation effectiveness includes 4 secondary indicators.

It can be seen from "Table II" that the economic dimension mainly includes 3 primary indicators and 13 secondary indicators. Among them, economic scale includes 8 secondary indicators, economic structure includes 3 secondary indicators, and economic quality includes 2 secondary indicators. The social dimension mainly includes 6 primary indicators and 21 secondary indicators. Among them, people's livelihood improvement includes 3 secondary indicators; education governance includes 4 secondary indicators; medical improvement includes 3 secondary indicators; insurance scale includes 5 secondary indicators; transportation scale includes 4 secondary indicators; and post and telecommunications scale includes 2 secondary indicators. The ecological dimension mainly includes 3 primary indicators and 14 secondary indicators. Among them, resource consumption includes 3 secondary indicators; ecological protection includes 6 secondary indicators; and environmental governance includes 5 secondary indicators. Integrating the four dimensions of technology, economy, society, and ecology, the rating index system includes a total of 63 initial indicators. 
TABLE II. INITIAL INDICATORS OF ECONOMIC, SOCIAL AND ECOLOGICAL DIMENSIONS OF THE COORDINATED DEVELOPMENT EVALUATION OF THE BEIJING-TIANJIN-HEBEI REGION

\begin{tabular}{|c|c|c|c|c|c|}
\hline \multirow[b]{2}{*}{ Dimension } & \multicolumn{2}{|r|}{ Indicator } & \multirow[b]{2}{*}{ Dimension } & \multicolumn{2}{|r|}{ Indicator } \\
\hline & $\begin{array}{l}\text { First-level } \\
\text { Indicator }\end{array}$ & Secondary index & & $\begin{array}{l}\text { First-level } \\
\text { Indicator }\end{array}$ & Secondary index \\
\hline \multirow{12}{*}{ Economics } & \multirow{8}{*}{ Economic scale } & Per capita GDP & \multirow{27}{*}{ 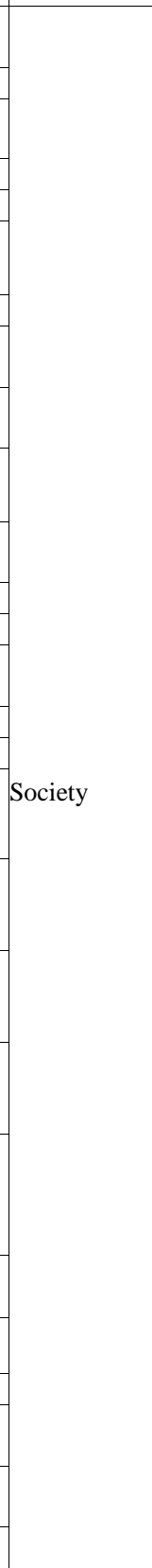 } & \multirow{5}{*}{$\begin{array}{l}\text { Improvement of } \\
\text { people's livelihood }\end{array}$} & \multirow{5}{*}{$\begin{array}{l}\text { Urban registered } \\
\text { unemployment rate } \\
\begin{array}{l}\text { Year-end balance of RMB } \\
\text { savings deposits of urban and } \\
\text { rural residents }\end{array} \\
\begin{array}{l}\text { Per capita disposable income } \\
\text { of urban residents }\end{array} \\
\end{array}$} \\
\hline & & GDP growth rate & & & \\
\hline & & General budget revenue of local governments & & & \\
\hline & & Total Investment in Fixed Assets & & & \\
\hline & & Total retail sales of social consumer goods & & & \\
\hline & & $\begin{array}{l}\text { The total import and export volume of the } \\
\text { place where the business entity is located }\end{array}$ & & \multirow{6}{*}{$\begin{array}{l}\text { Educational } \\
\text { governance }\end{array}$} & $\begin{array}{l}\text { Enrollment of ordinary } \\
\text { colleges and universities }\end{array}$ \\
\hline & & Added value of secondary industry & & & \\
\hline & & Industrial added value & & & $\begin{array}{l}\text { Student-teacher ratio in } \\
\text { ordinary universities }\end{array}$ \\
\hline & \multirow{3}{*}{$\begin{array}{l}\text { Economic } \\
\text { structure }\end{array}$} & $\begin{array}{l}\text { The ratio of output value of primary industry } \\
\text { to GDP }\end{array}$ & & & $\begin{array}{l}\text { Local fiscal expenditure on } \\
\text { education }\end{array}$ \\
\hline & & $\begin{array}{l}\text { The ratio of output value of the secondary } \\
\text { industry to GDP }\end{array}$ & & & \multirow{2}{*}{$\begin{array}{l}\text { Number of persons aged } 6 \text { and } \\
\text { above with education }\end{array}$} \\
\hline & & $\begin{array}{l}\text { The ratio of output value of tertiary industry } \\
\text { to GDP }\end{array}$ & & & \\
\hline & $\begin{array}{l}\text { Economic } \\
\text { quality }\end{array}$ & \begin{tabular}{|l|} 
Overall labor productivity \\
Urbanization rate of permanent population
\end{tabular} & & \multirow{3}{*}{$\begin{array}{l}\text { Medical } \\
\text { improvement }\end{array}$} & \multirow{2}{*}{$\begin{array}{l}\text { Number of medical and health } \\
\text { institutions } \\
\begin{array}{l}\text { Number of beds in medical } \\
\text { and health institutions }\end{array}\end{array}$} \\
\hline \multirow{15}{*}{ Ecology } & \multirow{3}{*}{$\begin{array}{l}\text { Resource } \\
\text { consumption }\end{array}$} & Total water consumption & & & \\
\hline & & Energy consumption & & & Number of health personnel \\
\hline & & Energy consumption per unit GDP & & \multirow{6}{*}{ Insurance scale } & Number of participants in the \\
\hline & \multirow{7}{*}{$\begin{array}{l}\text { Ecological } \\
\text { Protection }\end{array}$} & Forest coverage rate & & & $\begin{array}{l}\text { basic medical insurance for } \\
\text { urban employees at the end of } \\
\text { the year }\end{array}$ \\
\hline & & Forest growing stock & & & $\begin{array}{l}\text { Number of urban employees } \\
\text { participating in pension } \\
\text { insurance }\end{array}$ \\
\hline & & $\begin{array}{l}\text { Local fiscal expenditure on environmental } \\
\text { protection }\end{array}$ & & & $\begin{array}{l}\text { Number of people } \\
\text { participating in unemployment } \\
\text { insurance }\end{array}$ \\
\hline & & $\begin{array}{l}\text { Investment in industrial pollution control was } \\
\text { completed }\end{array}$ & & & $\begin{array}{l}\text { Number of participants in } \\
\text { work injury insurance at the } \\
\text { end of year }\end{array}$ \\
\hline & & $\begin{array}{l}\text { Investment in wastewater treatment project } \\
\text { was completed }\end{array}$ & & & $\begin{array}{l}\text { Number of people } \\
\text { participating in maternity } \\
\text { insurance at the end of the } \\
\text { year }\end{array}$ \\
\hline & & Investment in the waste gas treatment project & & \multirow{5}{*}{ Traffic scale } & Volume of freight traffic \\
\hline & & was completed & & & Passenger capacity \\
\hline & \multirow{5}{*}{$\begin{array}{l}\text { Environmental } \\
\text { governance }\end{array}$} & Household garbage clearance volume & & & \multirow{2}{*}{ Highway mileage } \\
\hline & & Discharge amount of wastewater & & & \\
\hline & & Chemical oxygen demand emissions & & & $\begin{array}{l}\text { Length of railroad lines in } \\
\text { service }\end{array}$ \\
\hline & & Ammonia nitrogen emissions & & \multirow{2}{*}{$\begin{array}{l}\text { Post and } \\
\text { telecommunications } \\
\text { scale }\end{array}$} & $\begin{array}{l}\text { Total gross of post and } \\
\text { telecommunications business }\end{array}$ \\
\hline & & Sulfur dioxide emissions & & & Year-end mobile phone users \\
\hline
\end{tabular}

\section{B. Quantitative screening methods of evaluation indicators}

As the science and technology, economic, social, and ecological dimensions of the Beijing-Tianjin-Hebei region involve many related indicators, the principal component - correlation analysis method is used to screen the indicators for dimensionality reduction. Principal component analysis is using the idea of dimensionality reduction to convert multiple indicators into a few comprehensive indicators (principal components), in which each principal component can reflect most of the information of the original variable. The principal component analysis method is used to 
screen the indicators of science and technology, economy, society and ecological dimensions, and the indicators that have a large contribution to the principal components are screened out, and the indicators of science and technology, economy, society and ecology are obtained. At the same time, due to the high correlation between the indicators and the phenomenon of information overlap, the principal component analysis method cannot solve this problem. At this time, the correlation analysis method is used to supplement the screening of indicators. The correlation analysis method can eliminate the index with high repeatability by calculating the correlation coefficient between the indexes, and eliminate the influence of the linear correlation of the indexes. This paper adopts the principal component analysis - correlation analysis method. And the initial index screening steps for the evaluation of the coordinated development of the Beijing-Tianjin-Hebei region are as the following:

First, it can use principal component analysis to quantitatively pre-screen the initial indicators according to the factor loading. Then, it can screen the index with the principal component factor load greater than 0.9, and the second or third principal component factor load with the largest absolute value.

Second, it is required to use correlation analysis method. According to the size of correlation coefficient, a secondary quantitative screening on the remaining indicators after principal component analysis and screening can be performed. In this paper, the author calculates the correlation coefficients between any two indicators under the secondary indicator level in the dimensions of science and technology, economy, society, and ecology in the Beijing-Tianjin-Hebei region, and sets the threshold value $M(0<M<1)$ of the index correlation coefficient. If the correlation coefficient of the two indicators is less than the threshold value $M$, then two indicators are retained at the same time; if the correlation coefficient between the two indicators is greater than the threshold value $\mathrm{M}$, the indicator with the smaller absolute value of the factor load in the two indicators is deleted, that is, the indicator with small influence on the evaluation result. In this paper, the threshold value $\mathrm{M}=0.9$.

\section{EMPIRICAL RESEARCH}

\section{A. The design of scientific and technological indicators for the evaluation of coordinated development in the Beijing-Tianjin-Hebei region}

According to "Table I", the technological dimension mainly includes technological innovation input indicator, technological innovation environment indicator, technological innovation output indicator, technological innovation effectiveness indicator. R\&D personnel $\left(\mathrm{X}_{1}\right), \mathrm{R} \& \mathrm{D}$ personnel full-time equivalent $\left(\mathrm{X}_{2}\right)$, and $\mathrm{R} \& \mathrm{D}$ personnel full-time equivalent in hightech industry $\left(\mathrm{X}_{3}\right)$ are selected as indicators of technological innovation input; $R \& D$ internal expenditure $\left(\mathrm{X}_{4}\right), \mathrm{R} \& \mathrm{D}$ internal expenditure in hightech industry $\left(\mathrm{X}_{5}\right)$ expenditures for new product development in high-tech industries $\left(\mathrm{X}_{6}\right), \quad \mathrm{R} \& \mathrm{D}$ expenditure input intensity $\left(\mathrm{X}_{7}\right)$, and local financial science and technology expenditures $\left(\mathrm{X}_{8}\right)$ are indicators of the technological innovation environment; number of patent applications granted $\left(X_{9}\right)$, number of patent applications accepted $\left(\mathrm{X}_{10}\right)$, number of invention patent applications authorized $\left(\mathrm{X}_{11}\right)$ are indicators of technological innovation output; the number of patents per 10,000 population $\left(\mathrm{X}_{12}\right)$, technology market turnover $\left(\mathrm{X}_{13}\right)$, sales revenue of new products in hightech industries $\left(\mathrm{X}_{14}\right)$, the export of new industrial products in high-tech industry $\left(\mathrm{X}_{15}\right)$ are the indicators of the effectiveness of technological innovation. According to the significance of each indicator, the principal component analysis method is used to make the first quantitative screening of the initial indicators of technological innovation. Using SPSS20 software, KMO and Bartlett tests were performed on 15 science and technology indicators in Beijing, Tianjin, Hebei, and Beijing-Tianjin-Hebei from 2009 to 2017 (see "Table III").

TABLE III. KMO AND B ARTLETT TEST OF TECHNOLOGICAL INDICATORS

\begin{tabular}{|l|l|l|}
\hline \multicolumn{2}{|c|}{ Items } & \multicolumn{1}{c|}{ Value } \\
\hline Kaiser-Meyer-Olkin measurement & with sufficient sampling & 0.767 \\
\hline \multirow{3}{*}{ Bartlett's sphericity test } & The approximate chi-square & 1554.987 \\
\cline { 2 - 3 } & Sig & 0 \\
\cline { 2 - 3 } & The total variance of the interpretation & $86.36 \%$ \\
\hline
\end{tabular}

The test results show that the KMO value of science and technology indicators is 0.767 , which is greater than the minimum value 0.5 , indicating that the initial indicator structure is reasonable and suitable for factor analysis. The Sig value of the Bartlett sphericity test is 0 , indicating that there is a correlation between the science and technology indicators, and the principal component can be extracted. The extracted principal components can explain $86.36 \%$ of the original indicator information. First, it is required to quantitatively pre-screen the initial scientific and technological indicators according to the size of the factor loading, and screen out the indicators with the principal component factor loading greater than 0.9 and the secondary or third principal component factor loading with the largest absolute value, and obtain the 
TABLE IV. PRE-SCREENING RESULTS OF PRINCIPAL COMPONENT OF SCIENTIFIC AND TECHNOLOGICAL INDICATORS

\begin{tabular}{|l|l|l|l|}
\hline $\begin{array}{c}\text { Indicator } \\
\text { layer }\end{array}$ & \multicolumn{1}{|c|}{$\begin{array}{c}\text { First principal component } \\
\text { factor loading }\end{array}$} & $\begin{array}{c}\text { Secondary principal } \\
\text { component factor loading }\end{array}$ & $\begin{array}{c}\text { Principal component } \\
\text { screening results }\end{array}$ \\
\hline $\mathrm{X}_{1}$ & 0.961 & -0.214 & Retain \\
\hline $\mathrm{X}_{2}$ & 0.958 & -0.206 & Retain \\
\hline $\mathrm{X}_{3}$ & 0.945 & -0.262 & Retain \\
\hline $\mathrm{X}_{4}$ & 0.362 & 0.384 & Delete \\
\hline $\mathrm{X}_{5}$ & 0.985 & -0.052 & Retain \\
\hline $\mathrm{X}_{6}$ & 0.989 & -0.001 & Retain \\
\hline $\mathrm{X}_{7}$ & 0.564 & 0.646 & Delete \\
\hline $\mathrm{X}_{8}$ & 0.992 & -0.017 & Retain \\
\hline $\mathrm{X}_{10}$ & 0.971 & -0.028 & Retain \\
\hline $\mathrm{X}_{11}$ & 0.938 & 0.216 & Retain \\
\hline $\mathrm{X}_{12}$ & 0.417 & 0.807 & Retain \\
\hline $\mathrm{X}_{13}$ & 0.95 & 0.226 & Retain \\
\hline $\mathrm{X}_{14}$ & 0.922 & -0.245 & Retain \\
\hline $\mathrm{X}_{15}$ & 0.602 & -0.5 & Delete \\
\hline
\end{tabular}

Secondly, it is required to carry out the secondary quantitative screening of scientific and technological indicators according to the size of the correlation coefficient. It is necessary to calculate the correlation coefficient (see "Table V") between any two indicators in the secondary indicator layer retained after passing the principal component screening, and use the threshold $\mathrm{M}$ value for screening. Among them, under the investment in technological innovation, $R \& D$ personnel $\left(\mathrm{X}_{1}\right), \mathrm{R} \& \mathrm{D}$ personnel full-time equivalent $\left(\mathrm{X}_{2}\right)$, and $\mathrm{R} \& \mathrm{D}$ personnel equivalent full-time equivalent in high-tech industry $\left(\mathrm{X}_{3}\right)$ are highly correlated, which is greater than the threshold value 0.9 , but R\&D personnel $\left(\mathrm{X}_{1}\right)$ has the largest factor loading among the three and has the largest contribution to the principal component, so $\mathrm{X}_{1}$ is retained. Under the environment of technological innovation, R\&D internal expenditures in high-tech industries $\left(\mathrm{X}_{5}\right)$, expenditures for new product development in high-tech industries $\left(\mathrm{X}_{6}\right)$, and local fiscal science and technology expenditures $\left(\mathrm{X}_{8}\right)$ are highly correlated, greater than the threshold value 0.9 , but the local fiscal science and technology expenditure $\left(\mathrm{X}_{8}\right)$ has the largest factor loading among the three, and has the largest contribution to the principal component, so $\mathrm{X}_{8}$ is retained. Under the output of technological innovation, the number of patent applications granted $\left(\mathrm{X}_{9}\right)$, the number of patent applications accepted $\left(\mathrm{X}_{10}\right)$, and the number of invention patent applications accepted $\left(\mathrm{X}_{11}\right)$ are highly correlated, which is greater than the threshold value 0.9. However, the number of patent applications accepted $\left(\mathrm{X}_{10}\right)$ has the largest factor loading among the three and has the largest contribution to the principal component, so $\mathrm{X}_{10}$ is retained. Under the effect of scientific and technological innovation, the correlation coefficient of patent ownership per 10,000 population $\left(\mathrm{X}_{12}\right)$, technology market turnover $\left(\mathrm{X}_{13}\right)$, and high-tech industry new product sales revenue $\left(\mathrm{X}_{14}\right)$ is less than the threshold value 0.9 , so $\mathrm{X}_{12}, \mathrm{X}_{13}$ and $\mathrm{X}_{14}$ are retained.

TABLE V. CORRELATION COEFFICIENTS OF SCIENTIFIC AND TECHNOLOGICAL INDICATORS

\begin{tabular}{|l|c|c|c|c|c|c|c|c|c|c|c|c|}
\hline & $\mathbf{X}_{\mathbf{1}}$ & $\mathbf{X}_{\mathbf{2}}$ & $\mathbf{X}_{\mathbf{3}}$ & $\mathbf{X}_{\mathbf{5}}$ & $\mathbf{X}_{\mathbf{6}}$ & $\mathbf{X}_{\mathbf{8}}$ & $\mathbf{X}_{\mathbf{9}}$ & $\mathbf{X}_{\mathbf{1 0}}$ & $\mathbf{X}_{\mathbf{1 1}}$ & $\mathbf{X}_{\mathbf{1 2}}$ & $\mathbf{X}_{\mathbf{1 3}}$ & $\mathbf{X}_{\mathbf{1 4}}$ \\
\hline $\mathrm{X}_{1}$ & 1.000 & 0.998 & 0.955 & 0.944 & 0.954 & 0.966 & 0.923 & 0.923 & 0.869 & 0.191 & 0.884 & 0.912 \\
\hline $\mathrm{X}_{2}$ & 0.998 & 1.000 & 0.946 & 0.933 & 0.950 & 0.960 & 0.904 & 0.905 & 0.856 & 0.198 & 0.882 & 0.917 \\
\hline $\mathrm{X}_{3}$ & 0.955 & 0.946 & 1.000 & 0.970 & 0.944 & 0.927 & 0.926 & 0.936 & 0.819 & 0.168 & 0.814 & 0.924 \\
\hline $\mathrm{X}_{5}$ & 0.944 & 0.933 & 0.970 & 1.000 & 0.985 & 0.970 & 0.981 & 0.985 & 0.919 & 0.366 & 0.912 & 0.902 \\
\hline $\mathrm{X}_{6}$ & 0.954 & 0.950 & 0.944 & 0.985 & 1.000 & 0.982 & 0.964 & 0.963 & 0.933 & 0.405 & 0.950 & 0.892 \\
\hline $\mathrm{X}_{8}$ & 0.966 & 0.960 & 0.927 & 0.970 & 0.982 & 1.000 & 0.967 & 0.964 & 0.944 & 0.400 & 0.959 & 0.905 \\
\hline $\mathrm{X}_{9}$ & 0.923 & 0.904 & 0.926 & 0.981 & 0.964 & 0.967 & 1.000 & 0.991 & 0.957 & 0.391 & 0.929 & 0.841 \\
\hline $\mathrm{X}_{10}$ & 0.923 & 0.905 & 0.936 & 0.985 & 0.963 & 0.964 & 0.991 & 1.000 & 0.938 & 0.390 & 0.915 & 0.874 \\
\hline $\mathrm{X}_{11}$ & 0.869 & 0.856 & 0.819 & 0.919 & 0.933 & 0.944 & 0.957 & 0.938 & 1.000 & 0.532 & 0.978 & 0.753 \\
\hline $\mathrm{X}_{12}$ & 0.191 & 0.198 & 0.168 & 0.366 & 0.405 & 0.400 & 0.391 & 0.390 & 0.532 & 1.000 & 0.571 & 0.257 \\
\hline $\mathrm{X}_{13}$ & 0.884 & 0.882 & 0.814 & 0.912 & 0.950 & 0.959 & 0.929 & 0.915 & 0.978 & 0.571 & 1.000 & 0.791 \\
\hline $\mathrm{X}_{14}$ & 0.912 & 0.917 & 0.924 & 0.902 & 0.892 & 0.905 & 0.841 & 0.874 & 0.753 & 0.257 & 0.791 & 1.000 \\
\hline
\end{tabular}

Through the use of principal component analysis and related analysis methods, it is finally determined that R\&D personnel, local financial science and technology expenditures, the number of patent 
applications accepted, the number of patents per 10,000 people, the turnover of the technology market, and the sales revenue of new products in high-tech industries are the technology dimension indicators (see "Table VI").

TABLE VI. SCIENTIFIC AND TECHNOLOGICAL INDICATORS FOR THE EVALUATION OF COORDINATED DEVELOPMENT IN THE BEIJING-TIANJIN-HEBEI REGION

\begin{tabular}{|c|c|c|c|}
\hline \multirow{2}{*}{ Dimension } & \multicolumn{2}{|r|}{ Indicator } & \multirow{2}{*}{ Unit } \\
\hline & First-level indicators & Secondary index & \\
\hline \multirow{6}{*}{$\begin{array}{l}\text { Scientific } \\
\text { and } \\
\text { technological } \\
\text { innovation }\end{array}$} & $\begin{array}{l}\text { Scientific and technological } \\
\text { innovation investment }\end{array}$ & R\&D staff & Person \\
\hline & $\begin{array}{l}\text { Technological innovation } \\
\text { environment }\end{array}$ & Local financial science and technology expenditure & 100 million yuan \\
\hline & \multirow{2}{*}{$\begin{array}{l}\text { Scientific and technological } \\
\text { innovation output }\end{array}$} & Number of patent applications accepted & Piece \\
\hline & & Number of patents per 10,000 people & Piece/ten thousand persons \\
\hline & \multirow{2}{*}{$\begin{array}{l}\text { Scientific and technological } \\
\text { innovation effect }\end{array}$} & Technology market turnover & 100 million yuan \\
\hline & & Sales revenue of new products in high-tech industry & 100 million yuan \\
\hline
\end{tabular}

\section{B. Design of economic indicators for the evaluation of coordinated development in the Beijing-Tianjin- Hebei region}

According to "Table I", economic indicators mainly include economic scale indicator, economic structure indicator and economic quality indicator. It is required to select per capita GDP ( $\left.\mathrm{Y}_{1}\right)$, GDP growth rate $\left(\mathrm{Y}_{2}\right)$, local fiscal general budget revenue $\left(\mathrm{Y}_{3}\right)$, total social fixed asset investment $\left(\mathrm{Y}_{4}\right)$, total retail sales of consumer goods $\left(\mathrm{Y}_{5}\right)$, total import and export volume of the place where the business entity is located $\left(\mathrm{Y}_{6}\right)$, the added value of the secondary industry $\left(\mathrm{Y}_{7}\right)$ and industrial added value $\left(\mathrm{Y}_{8}\right)$ are indicators of economic scale; the ratio of output value of primary industry to GDP $\left(\mathrm{Y}_{9}\right)$, the ratio of output value of secondary industry to GDP $\left(\mathrm{Y}_{10}\right)$, and the ratio of output value of tertiary industry to GDP $\left(\mathrm{Y}_{11}\right)$ are indicators of economic structure; the overall labor productivity $\left(\mathrm{Y}_{12}\right)$ and the urbanization rate of permanent population $\left(\mathrm{Y}_{13}\right)$ are indicators of economic quality. According to the significance of each indicator, the principal component analysis method is used to make quantitative prescreening of economic indicators. It is required to use SPSS20 to perform KMO and Bartlett tests on 13 economic indicators in Beijing, Tianjin, Hebei, and Beijing-Tianjin-Hebei from 2009 to 2017 (see "Table VII").

TABLE VII. KMO AND BARTLETT TEST OF ECONOMIC INDICATORS

\begin{tabular}{|l|l|l|}
\hline \multicolumn{2}{|c|}{ Items } & \multicolumn{1}{c|}{ Value } \\
\hline Kaiser-Meyer-Olkin measurement with sufficient sampling & 0.683 \\
\hline \multirow{3}{*}{ Bartlett's sphericity test } & The approximate chi-square & 1363.098 \\
\cline { 2 - 3 } & Sig & 0 \\
\cline { 2 - 3 } & The total variance of the interpretation & $91.5 \%$ \\
\hline
\end{tabular}

The test results show that the KMO value of economic indicators is 0.683 , which is greater than the minimum value 0.5 , indicating that the initial indicator structure is reasonable and suitable for factor analysis; the Sig value of Bartlett's sphericity test is 0 , indicating that there is a correlation between economic indicators, and the principal component can be extracted. The extracted principal components can explain $91.5 \%$ of the original indicator information. According to the size of the factor loading, it is required to carry out a secondary quantitative screening of economic development indicators, and screen out the indicators with the first principal component factor loading greater than 0.9 and the second or third principal component factor loading with the largest absolute value. Then, the principal component screening results of the economic indicators are obtained (see "Table VIII").

TABLE VIII. PRE-SCREENING RESULTS OF PRINCIPAL COMPONENT OF ECONOMIC INDICATORS

\begin{tabular}{|l|l|l|l|l|}
\hline $\begin{array}{c}\text { Indicator } \\
\text { layer }\end{array}$ & \multicolumn{1}{|c|}{$\begin{array}{c}\text { First principal } \\
\text { component factor } \\
\text { loading }\end{array}$} & $\begin{array}{c}\text { Second principal } \\
\text { component factor } \\
\text { loading }\end{array}$ & $\begin{array}{c}\text { The third principal } \\
\text { component factor } \\
\text { loading }\end{array}$ & $\begin{array}{c}\text { Principal component } \\
\text { screening results }\end{array}$ \\
\hline$Y_{1}$ & 0.849 & -0.236 & -0.138 & Delete \\
\hline$Y_{2}$ & -0.059 & -0.205 & 0.958 & Retain \\
\hline$Y_{3}$ & 0.242 & 0.954 & -0.081 & Retain \\
\hline$Y_{4}$ & -0.349 & 0.891 & -0.219 & Delete \\
\hline$Y_{5}$ & -0.046 & 0.982 & -0.135 & Retain \\
\hline$Y_{6}$ & 0.472 & 0.781 & 0.242 & Delete \\
\hline$Y_{7}$ & -0.405 & 0.892 & -0.136 & Delete \\
\hline
\end{tabular}




\begin{tabular}{|l|l|l|l|l|}
\hline $\begin{array}{c}\text { Indicator } \\
\text { layer }\end{array}$ & $\begin{array}{c}\text { First principal } \\
\text { component factor } \\
\text { loading }\end{array}$ & $\begin{array}{c}\text { Second principal } \\
\text { component factor } \\
\text { loading }\end{array}$ & $\begin{array}{c}\text { The third principal } \\
\text { component factor } \\
\text { loading }\end{array}$ & $\begin{array}{c}\text { Principal component } \\
\text { screening results }\end{array}$ \\
\hline $\mathrm{Y}_{8}$ & -0.411 & 0.900 & -0.070 & Retain \\
\hline $\mathrm{Y}_{9}$ & -0.880 & 0.163 & -0.158 & Delete \\
\hline $\mathrm{Y}_{10}$ & -0.875 & -0.142 & 0.021 & Delete \\
\hline $\mathrm{Y}_{11}$ & 0.957 & 0.070 & 0.028 & Retain \\
\hline $\mathrm{Y}_{12}$ & 0.956 & -0.063 & -0.114 & Retain \\
\hline $\mathrm{Y}_{13}$ & 0.888 & -0.333 & 0.089 & Delete \\
\hline
\end{tabular}

According to the size of the correlation coefficient, the second quantitative screening of economic indicators is carried out. By calculating the correlation coefficient between any two indicators in the secondary index layer retained after quantitative pre-screening (see "Table IX"), the threshold value $\mathrm{M}$ is used for screening. Among them, under the economic scale, local fiscal general budget revenue $\left(\mathrm{Y}_{3}\right)$, and total retail sales of social consumer goods $\left(\mathrm{Y}_{5}\right)$ are highly correlated, which is greater than the threshold value 0.9 , but the factor loading of total retail sales of social consumer goods $\left(\mathrm{Y}_{5}\right)$ is the largest, which contributes the most to the principal component. Therefore, $\mathrm{Y}_{5}$ is retained. The correlation coefficient among GDP growth rate $\left(\mathrm{Y}_{2}\right)$, total retail sales of consumer goods $\left(\mathrm{Y}_{5}\right)$ and industrial added value $\left(\mathrm{Y}_{8}\right)$ is less than the threshold value 0.9 , so all of them are retained. Under the economic structure and economic quality, the remaining indicators are the proportion of tertiary industry output value to $\operatorname{GDP}\left(\mathrm{Y}_{11}\right)$ and total labor productivity $\left(\mathrm{Y}_{12}\right)$, so they are retained.

TABLE IX. CORRELATION COEFFICIENT OF ECONOMIC INDICATORS

\begin{tabular}{|l|l|l|l|l|l|l|}
\hline & \multicolumn{1}{|c|}{$\mathbf{Y}_{\mathbf{2}}$} & \multicolumn{1}{|c|}{$\mathbf{Y}_{\mathbf{3}}$} & \multicolumn{1}{c|}{$\mathbf{Y}_{\mathbf{5}}$} & \multicolumn{1}{c|}{$\mathbf{Y}_{\mathbf{8 1}}$} & \multicolumn{1}{c|}{$\mathbf{Y}_{\mathbf{1 2}}$} \\
\hline $\mathrm{Y}_{2}$ & 1.000 & -0.270 & -0.312 & -0.222 & -0.058 & -0.118 \\
\hline $\mathrm{Y}_{3}$ & -0.270 & 1.000 & 0.944 & 0.765 & 0.272 & 0.189 \\
\hline $\mathrm{Y}_{5}$ & -0.312 & 0.944 & 1.000 & 0.898 & 0.028 & -0.080 \\
\hline $\mathrm{Y}_{8}$ & -0.222 & 0.765 & 0.898 & 1.000 & -0.372 & -0.448 \\
\hline $\mathrm{Y}_{11}$ & -0.058 & 0.272 & 0.028 & -0.372 & 1.000 & 0.909 \\
\hline $\mathrm{Y}_{12}$ & -0.118 & 0.189 & -0.080 & -0.448 & 0.909 & 1.000 \\
\hline
\end{tabular}

By using principal component analysis and correlation analysis, GDP growth rate $\left(\mathrm{Y}_{2}\right)$, total retail sales of consumer goods $\left(\mathrm{Y}_{5}\right)$, industrial added value
$\left(\mathrm{Y}_{8}\right)$, the proportion of tertiary industry output value to GDP $\left(\mathrm{Y}_{11}\right)$, and total labor productivity $\left(\mathrm{Y}_{12}\right)$ are finally determined as economic indicators (see "Table $\mathrm{X}$ ").

TABLE X. ECONOMIC INDICATORS OF THE EVALUATION OF COORDINATED DEVELOPMENT IN BEIJING-TIANJIN-HEBEI REGION

\begin{tabular}{|l|l|l|l|}
\hline \multirow{2}{*}{ Dimension } & \multicolumn{2}{|c|}{ Indicator } & \multirow{2}{*}{ Unit } \\
\cline { 2 - 4 } & $\begin{array}{l}\text { First-level } \\
\text { indicators }\end{array}$ & Secondary index & $\%$ \\
\hline \multirow{4}{*}{ Economics } & \multirow{2}{*}{\begin{tabular}{l} 
Economic scale \\
\cline { 2 - 4 }
\end{tabular}} & GDP growth rate & 100 million yuan \\
\cline { 2 - 4 } & Total retail sales of social consumer goods & 100 million yuan \\
\cline { 2 - 4 } & $\begin{array}{l}\text { Economic } \\
\text { Structure }\end{array}$ & $\begin{array}{l}\text { The ratio of output value of tertiary industry to } \\
\text { GDP }\end{array}$ & Yuan/person \\
\cline { 2 - 4 } & Economic quality & Overall labor productivity & \\
\hline
\end{tabular}

\section{The design of social indicators for the evaluation of coordinated development in the Beijing-Tianjin- Hebei region}

According to "Table I", social indicators mainly include people's livelihood improvement, education governance, scale of post and telecommunications, scale of transportation, improvement of medical treatment, and scale of insurance. The urban registered unemployment rate $\left(Z_{1}\right)$, RMB deposit balance of urban and rural residents at year end $\left(Z_{2}\right)$, and the per capita disposable income of urban residents $\left(Z_{3}\right)$ are selected as indicators for improving people's livelihood; enrollment of ordinary colleges and universities $\left(Z_{4}\right)$, ratio of students to teachers in ordinary colleges and universities $\left(Z_{5}\right)$ ), local fiscal expenditure on education $\left(Z_{6}\right)$, the number of people aged 6 and over with education $\left(Z_{7}\right)$ are indicators of education governance; total post and telecommunications business $\left(\mathrm{Z}_{8}\right)$ and year-end mobile phone users $\left(Z_{9}\right)$ are indicators of post and telecommunications scale; freight volume $\left(Z_{10}\right)$, passenger traffic $\left(Z_{11}\right)$, highway mileage $\left(Z_{12}\right)$, railway operating mileage $\left(Z_{13}\right)$ are the traffic scale indicators; the number of beds in medical and health institutions $\left(Z_{14}\right)$, the number of medical and health institutions $\left(\mathrm{Z}_{15}\right)$, and the number of health personnel $\left(\mathrm{Z}_{16}\right)$ are 
medical improvement indicator; the number of urban employees participating in pension insurance $\left(Z_{17}\right)$, the number of persons participating unemployment insurance $\left(\mathrm{Z}_{18}\right)$, the number of urban employees participating in basic medical insurance at the end of the year $\left(Z_{19}\right)$, the number of participants participating in work injury insurance at the end of the year $\left(Z_{20}\right)$, and the number of participants participating maternity insurance at the end of the year $\left(Z_{21}\right)$ are indicators of insurance scale. According to the significance of each indicator, the principal component analysis method is used to make the quantitative screening of social indicators. In order to make the sample structure reasonable, the 21 indicators were divided into two parts for testing. First, it is required to perform KMO and Bartlett tests on the first 16 livelihood and welfare indicators and the last 5 social security indicators in Beijing, Tianjin, Hebei, and Beijing-Tianjin-Hebei from 2009 to 2017 (see "Table XI").

TABLE XI. KMO AND BARTLETT TEST OF SOCIAL INDICATORS

\begin{tabular}{|c|c|c|c|}
\hline \multirow{2}{*}{\multicolumn{2}{|c|}{ Items }} & $\begin{array}{c}\text { Well-being of the } \\
\text { people }\end{array}$ & $\begin{array}{c}\text { Social } \\
\text { insurance }\end{array}$ \\
\hline & & Value & Value \\
\hline \multicolumn{2}{|c|}{ Kaiser-Meyer-Olkin measurement with sufficient sampling } & 0.808 & 0.742 \\
\hline \multirow{3}{*}{ Bartlett's sphericity test } & The approximate chi-square & 1650.567 & 578.545 \\
\hline & Sig & 0 & 0 \\
\hline & The total variance of the interpretation & $89.90 \%$ & $98.09 \%$ \\
\hline
\end{tabular}

The test results show that the KMO value of the people's livelihood and welfare indicator is 0.808 , and that of the social security is 0.742 , both of which are greater than the minimum value 0.5 , indicating that the initial indicator structure is reasonable and suitable for factor analysis; the Sig value of the Bartlett sphericity test is 0 , indicating that there is a correlation between social indicators, and the principal component can be extracted. The extracted principal components can explain $89.90 \%$ and $98.09 \%$ of the original indicator information respectively. First, it is required to perform the first quantitative screening of social indicators according to the size of the factor loading, and screen out the indicators with the principal component factor loading greater than 0.9 and the second or third principal component factor loading with the largest absolute value, so as to obtain the principal component screening results of the social indicators (see "Table XII").

TABLE XII. PRE-SCREENING RESULTS OF PRINCIPAL COMPONENTS OF SOCIAL INDICATORS

\begin{tabular}{|c|c|c|c|c|}
\hline Indicator & $\begin{array}{l}\text { First principal } \\
\text { component } \\
\text { Factor loading }\end{array}$ & $\begin{array}{l}\text { Second principal } \\
\text { component } \\
\text { Factor loading }\end{array}$ & $\begin{array}{c}\text { The third principal } \\
\text { component } \\
\text { Factor loading }\end{array}$ & $\begin{array}{c}\text { Principal component } \\
\text { screening } \\
\text { Result }\end{array}$ \\
\hline $\mathrm{Z}_{1}$ & 0.257 & 0.907 & 0.161 & Retain \\
\hline $\mathrm{Z}_{2}$ & 0.907 & -0.373 & 0.106 & Retain \\
\hline $\mathrm{Z}_{3}$ & -0.132 & -0.786 & 0.444 & Delete \\
\hline $\mathrm{Z}_{4}$ & 0.900 & -0.291 & 0.220 & Retain \\
\hline $\mathrm{Z}_{5}$ & 0.359 & -0.044 & 0.655 & Retain \\
\hline $\mathrm{Z}_{6}$ & 0.977 & 0.007 & -0.128 & Retain \\
\hline $\mathrm{Z}_{7}$ & 0.174 & 0.816 & 0.246 & Delete \\
\hline $\mathrm{Z}_{8}$ & 0.817 & -0.325 & -0.083 & Delete \\
\hline $\mathrm{Z}_{9}$ & 0.972 & -0.159 & 0.072 & Retain \\
\hline $\mathrm{Z}_{10}$ & 0.958 & 0.235 & 0.006 & Retain \\
\hline $\mathrm{Z}_{11}$ & 0.651 & -0.251 & -0.568 & Delete \\
\hline $\mathrm{Z}_{12}$ & 0.959 & 0.224 & -0.021 & Retain \\
\hline $\mathrm{Z}_{13}$ & 0.982 & 0.137 & 0.030 & Retain \\
\hline $\mathrm{Z}_{14}$ & 0.994 & 0.016 & 0.035 & Retain \\
\hline$Z_{15}$ & 0.939 & 0.254 & -0.104 & Retain \\
\hline $\mathrm{Z}_{16}$ & 0.992 & -0.116 & -0.013 & Retain \\
\hline $\mathrm{Z}_{17}$ & 0.991 & & & Retain \\
\hline $\mathrm{Z}_{18}$ & 0.984 & & & Retain \\
\hline $\mathrm{Z}_{19}$ & 0.997 & & & Retain \\
\hline $\mathrm{Z}_{20}$ & 0.997 & & & Retain \\
\hline $\mathrm{Z}_{21}$ & 0.983 & & & Retain \\
\hline
\end{tabular}

According to the size of the correlation coefficient, the second quantitative screening of social indicators is carried out. By calculating the correlation coefficient (see "Table XIII") in the secondary index layer retained 
after quantitative pre-screening, the threshold value $\mathrm{M}$ is used for screening. Among them, with the improvement of people's livelihood, the correlation coefficient between the urban registered unemployment rate $\left(\mathrm{Z}_{1}\right)$ and the $\mathrm{RMB}$ deposit balance of urban and rural residents at year end $\left(Z_{2}\right)$ is less than the threshold value 0.9 , while $Z_{1}$ and $Z_{2}$ are retained; under the governance of education, the correlation coefficient among the enrollment of ordinary colleges and universities $\left(\mathrm{Z}_{4}\right)$, the ratio of students to teachers in colleges and universities $\left(Z_{5}\right)$ and the local financial expenditure on education $\left(Z_{6}\right)$ is lower than the threshold value 0.9 , while $Z_{5}$ and $Z_{6}$ are retained; under the scale of post and telecommunications, the end-ofyear mobile phone users $\left(Z_{9}\right)$ are retained; under the traffic scale, freight volume $\left(Z_{10}\right)$, highway mileage $\left(Z_{12}\right)$ and railway operating mileage $\left(Z_{13}\right)$ are highly correlated, which are greater than the threshold value 0.9 , but the factor loading of railway operating mileage (Z13) is the largest, which contributes the most to the principal component, so $\mathrm{Z}_{13}$ is retained; with the medical improvement, the number of beds in health institutions $\left(Z_{14}\right)$, the number of medical institutions $\left(Z_{15}\right)$ and the number of health personnel $\left(Z_{16}\right)$ are highly correlated, which is greater than the threshold value of 0.9 , but the factor loading of the number of beds in medical and health institutions $\left(Z_{14}\right)$ is the largest, which contributes the most to the principal component, so $\mathrm{Z}_{14}$ is retained. Under the scale of insurance, the number of urban employees participating in endowment insurance $\left(\mathrm{Z}_{17}\right)$, unemployment insurance $\left(Z_{18}\right)$, urban employees' basic medical insurance $\left(Z_{19}\right)$, industrial injury insurance $\left(Z_{20}\right)$ and birth insurance $\left(Z_{21}\right)$ are highly correlated, which is higher than the threshold value of 0.9. However, compared with the number of insured at the end of the year $\left(Z_{20}\right)$, the number of urban workers participating in the basic medical insurance at the end of the year $\left(Z_{19}\right)$ is frequently used, so $Z_{19}$ is retained.

TABLE XIII. CORRELATION COEFFICIENT OF SOCIAL INDICATORS

\begin{tabular}{|c|c|c|c|c|c|c|c|c|c|c|c|c|c|c|c|c|c|}
\hline & $\mathrm{Z}_{1}$ & $\mathbf{Z}_{2}$ & $\mathbf{Z}_{4}$ & $\mathbf{Z}_{5}$ & $Z_{6}$ & $Z_{9}$ & $Z_{10}$ & $Z_{12}$ & $Z_{13}$ & $Z_{14}$ & $Z_{15}$ & $\mathrm{Z}_{16}$ & $Z_{17}$ & $Z_{18}$ & $Z_{19}$ & $\mathbf{Z}_{20}$ & $\mathbf{Z}_{21}$ \\
\hline $\mathrm{Z}_{1}$ & 1.000 & -0.073 & 0.262 & 0.791 & 0.034 & 0.124 & 0.465 & 0.426 & 0.372 & 0.275 & 0.427 & 0.148 & -0.088 & -0.333 & -0.206 & -0.174 & -0.143 \\
\hline $\mathrm{Z}_{2}$ & -0.073 & 1.000 & 0.870 & -0.099 & 0.983 & 0.968 & 0.794 & 0.774 & 0.841 & 0.906 & 0.725 & 0.945 & 0.987 & 0.914 & 0.946 & 0.966 & 0.972 \\
\hline$Z_{4}$ & 262 & 0.870 & 1.000 & 0.162 & 0.858 & .932 & 0.927 & 0.918 & 0.940 & 0.955 & .913 & 0.970 & 0.894 & 0.787 & 0.859 & 0.876 & 0.835 \\
\hline $\mathrm{Z}_{5}$ & 0.791 & -0.099 & 0.162 & 1.000 & 0.003 & 0.055 & 0.345 & 0.305 & 0.253 & 0.178 & 0.319 & 0.080 & -0.106 & -0.294 & -0.204 & -0.181 & -0.135 \\
\hline $\mathrm{Z}_{6}$ & 0.034 & 0.983 & 0.858 & 0.003 & 1.000 & 0.961 & 0.812 & 0.768 & 0.840 & 0.900 & 0.710 & 0.926 & 0.968 & 0.868 & 0.912 & 0.934 & 0.957 \\
\hline$Z_{9}$ & 0.124 & 0.968 & 0.932 & 0.055 & 0.961 & 1.000 & 0.913 & 0.898 & 0.941 & 0.976 & 0.860 & 0.986 & 0.952 & 0.832 & 0.890 & 0.916 & 0.930 \\
\hline $\mathrm{Z}_{10}$ & 0.465 & 0.794 & 0.927 & 0.345 & 0.812 & 0.913 & 1.000 & 0.977 & 0.981 & 0.965 & 0.956 & 0.925 & 0.775 & 0.585 & 0.683 & 0.720 & 0.726 \\
\hline $\mathrm{Z}_{12}$ & 0.426 & 0.774 & 0.918 & 0.305 & 0.768 & 0.898 & 0.977 & 1.000 & 0.991 & 0.967 & 0.991 & 0.927 & 0.751 & 0.567 & 0.661 & 0.701 & 0.701 \\
\hline$Z_{13}$ & 0.372 & 0.841 & 0.940 & 0.253 & 0.840 & 0.941 & 0.981 & 0.991 & 1.000 & 0.990 & 0.970 & 0.959 & 0.817 & 0.641 & 0.730 & 0.769 & 0.770 \\
\hline$Z_{14}$ & 0.275 & 0.906 & 0.955 & 0.178 & 0.900 & 0.976 & 0.965 & 0.967 & 0.990 & 1.000 & 0.940 & 0.986 & 0.886 & 0.729 & 0.807 & 0.843 & 0.841 \\
\hline$Z_{15}$ & 0.427 & 0.725 & 0.913 & 0.319 & 0.710 & 0.860 & 0.956 & 0.991 & 0.970 & 0.940 & 1.000 & 0.905 & 0.716 & 0.547 & 0.637 & 0.672 & 0.663 \\
\hline$Z_{16}$ & 0.148 & 0.945 & 0.970 & 0.080 & 0.926 & 0.986 & 0.925 & 0.927 & 0.959 & 0.986 & 0.905 & 1.000 & 0.943 & 0.829 & 0.891 & 0.916 & 0.904 \\
\hline$Z_{17}$ & -0.088 & 0.987 & 0.894 & -0.106 & 0.968 & 0.952 & 0.775 & 0.751 & 0.817 & 0.886 & 0.716 & 0.943 & 1.000 & 0.954 & 0.982 & 0.991 & 0.982 \\
\hline$Z_{18}$ & -0.333 & 0.914 & 0.787 & -0.294 & 0.868 & 0.832 & 0.585 & 0.567 & 0.641 & 0.729 & 0.547 & 0.829 & 0.954 & 1.000 & 0.990 & 0.979 & 0.951 \\
\hline$Z_{19}$ & -0.206 & 0.946 & 0.859 & -0.204 & 0.912 & 0.890 & 0.683 & 0.661 & 0.730 & 0.807 & 0.637 & 0.891 & 0.982 & 0.990 & 1.000 & 0.996 & 0.967 \\
\hline $\mathrm{Z}_{20}$ & -0.174 & 0.966 & 0.876 & -0.181 & 0.934 & 0.916 & 0.720 & 0.701 & 0.769 & 0.843 & 0.672 & 0.916 & 0.991 & 0.979 & 0.996 & 1.000 & 0.969 \\
\hline$Z_{21}$ & -0.143 & 0.972 & 0.835 & -0.135 & 0.957 & 0.930 & 0.726 & 0.701 & 0.770 & 0.841 & 0.663 & 0.904 & 0.982 & 0.951 & 0.967 & 0.969 & 1.000 \\
\hline
\end{tabular}

Through principal component analysis and related analysis methods, the town's registered unemployment rate $\left(Z_{1}\right), R M B$ deposit balance of urban and rural residents at year end $\left(Z_{2}\right)$, the number of students enrolled in ordinary colleges and universities $\left(Z_{4}\right)$, the student-teacher ratio in ordinary colleges and universities $\left(Z_{5}\right)$, and local financial government expenditure on education $\left(Z_{6}\right)$, mobile phone users at the end of the year $\left(Z_{9}\right)$, road operating mileage $\left(Z_{13}\right)$, the number of beds in medical and health institutions $\left(\mathrm{Z}_{14}\right)$, and the number of participants in the basic medical insurance for urban employees at the end of the year $\left(Z_{19}\right)$ are social development indicators (see "Table XIV") .

TABLE XIV. SOCIAL INDICATORS FOR THE EVALUATION OF COORDINATED DEVELOPMENT IN THE BEIJING-TIANJIN-HEBEI REGION

\begin{tabular}{|c|c|c|c|}
\hline \multirow{2}{*}{ Dimension } & \multicolumn{2}{|r|}{ Indicator } & \multirow{2}{*}{ Unit } \\
\hline & First-level indicators & Secondary index & \\
\hline \multirow{8}{*}{ Society } & \multirow[b]{2}{*}{$\begin{array}{l}\text { Improvement of people's } \\
\text { livelihood }\end{array}$} & Urban registered unemployment rate & $\%$ \\
\hline & & $\begin{array}{l}\text { Year-end balance of RMB savings deposits of urban } \\
\text { and rural residents }\end{array}$ & 100 million yuan \\
\hline & \multirow{3}{*}{ Educational governance } & Enrollment of ordinary colleges and universities & Thousands of people \\
\hline & & Student-teacher ratio in ordinary universities & - \\
\hline & & Local fiscal expenditure on education & 100 million yuan \\
\hline & Post and telecommunications scale & Year-end mobile phone users & Thousands of households \\
\hline & Traffic scale & Length of railroad lines in service & Thousands of kilometres \\
\hline & Medical improvement & Number of beds in medical and health institutions & Thousands of beds \\
\hline
\end{tabular}




\begin{tabular}{|l|l|l|l|}
\hline & Insurance scale & $\begin{array}{l}\text { Number of participants in the basic medical } \\
\text { insurance for urban employees at the end of the year }\end{array}$ & Thousands of people \\
\hline
\end{tabular}

\section{Ecological indicator design of the evaluation for coordinated development in Beijing-Tianjin-Hebei region}

According to "Table I", ecological indicators mainly include resource consumption, ecological protection and environmental pollution. Energy consumption $\left(\mathrm{V}_{1}\right)$, energy consumption per unit GDP $\left(\mathrm{V}_{2}\right)$ and total water consumption $\left(\mathrm{V}_{3}\right)$ are selected as resource consumption indicators; forest coverage rate $\left(\mathrm{V}_{4}\right)$, forest stock volume $\left(\mathrm{V}_{5}\right)$, local fiscal environmental protection expenditure $\left(\mathrm{V}_{6}\right)$ and investment in wastewater treatment project completed $\left(\mathrm{V}_{7}\right)$, investment in waste water treatment project $\left(\mathrm{V}_{8}\right)$ and investment completed in waste gas treatment project $\left(\mathrm{V}_{9}\right)$ are ecological protection indicators; household garbage clearance volume $\left(\mathrm{V}_{10}\right)$, wastewater discharge $\left(\mathrm{V}_{11}\right)$, COD demand $\left(\mathrm{v}_{12}\right)$, ammonia nitrogen emission $\left(\mathrm{V}_{13}\right)$ and sulfur dioxide emission $\left(\mathrm{V}_{14}\right)$ are environmental pollution indicators. The principal component analysis method is used to make the quantitative screening of ecological indicators. Firstly, it is required to perform $\mathrm{KMO}$ and Bartlett test on 14 ecological indicators of Beijing, Tianjin, Hebei and Beijing-Tianjin-Hebei region from 2009 to 2017 respectively (see "Table $\mathrm{XV}$ ).

TABLE XV. KMO AND BARTLETT TESTS OF ECOLOGICAL INDICATORS

\begin{tabular}{|l|l|l|}
\hline \multicolumn{2}{|c|}{ Items } & \multicolumn{1}{c|}{ Value } \\
\hline Kaiser-Meyer-Olkin measurement with sufficient sampling & 0.742 \\
\hline \multirow{3}{*}{ Bartlett's sphericity test } & The approximate chi-square & 1337.745 \\
\cline { 2 - 3 } & Sig & 0 \\
\cline { 2 - 3 } & The total variance of the interpretation & $89.60 \%$ \\
\hline
\end{tabular}

The test results show that the KMO value of the ecological indicators is 0.742 , which is greater than the minimum value of 0.5 , indicating that the initial indicator structure is reasonable and suitable for factor analysis; the Sig value of the Bartlett sphericity test is 0 , indicating that there is a correlation between ecological indicators, and the principal component can be extracted. The extracted principal components can explain $89.60 \%$ of the original indicator information.
First, it is required to carry out quantitative prescreening of ecological indicators according to the size of the factor loading, and screen out the indicator with the principal component factor loading greater than 0.9 and the second or third principal component factor loading with the largest absolute value, and obtain the principal component screening results of the ecological indicators (see "Table XVI").

TABLE XVI. PRE-SCREENING RESULTS OF PRINCIPAL COMPONENTS OF ECOLOGICAL INDICATORS

\begin{tabular}{|l|l|l|l|l|}
\hline Indicator & \multicolumn{1}{|c|}{$\begin{array}{c}\text { First principal } \\
\text { component factor } \\
\text { loading }\end{array}$} & $\begin{array}{c}\text { Secondary principal } \\
\text { component factor } \\
\text { loading }\end{array}$ & $\begin{array}{c}\text { Third principal } \\
\text { component factor } \\
\text { loading }\end{array}$ & $\begin{array}{c}\text { Principal } \\
\text { component } \\
\text { screening results }\end{array}$ \\
\hline $\mathrm{V}_{1}$ & 0.978 & 0.052 & 0.033 & Retain \\
\hline $\mathrm{V}_{2}$ & 0.537 & -0.661 & 0.275 & Delete \\
\hline $\mathrm{V}_{3}$ & 0.974 & -0.027 & 0.159 & Retain \\
\hline $\mathrm{V}_{4}$ & 0.031 & 0.595 & 0.640 & Retain \\
\hline $\mathrm{V}_{5}$ & 0.957 & -0.055 & 0.189 & Retain \\
\hline $\mathrm{V}_{6}$ & 0.575 & 0.726 & -0.127 & Retain \\
\hline $\mathrm{V}_{7}$ & 0.826 & 0.116 & -0.491 & Delete \\
\hline $\mathrm{V}_{8}$ & 0.739 & -0.443 & 0.048 & Delete \\
\hline $\mathrm{V}_{9}$ & 0.779 & 0.158 & -0.492 & Delete \\
\hline $\mathrm{V}_{10}$ & 0.770 & 0.542 & 0.163 & Delete \\
\hline $\mathrm{V}_{11}$ & 0.959 & 0.203 & 0.078 & Retain \\
\hline $\mathrm{V}_{12}$ & 0.912 & -0.177 & -0.040 & Retain \\
\hline $\mathrm{V}_{13}$ & 0.929 & -0.305 & 0.169 & Retain \\
\hline $\mathrm{V}_{14}$ & 0.958 & -0.118 & -0.030 & Retain \\
\hline
\end{tabular}

Secondly, according to the size of the correlation coefficient, the secondary quantitative screening of ecological indicators is carried out. By calculating the correlation coefficient between any two indicators in the secondary index layer retained after quantitative pre-screening (see "Table III-Table XVII"), the threshold value $\mathrm{M}$ is used for screening. Among them, under resource consumption, energy consumption $\left(\mathrm{V}_{1}\right)$ is highly correlated with total water consumption $\left(\mathrm{V}_{3}\right)$, which is greater than the threshold value of 0.9 , but the factor loading of energy consumption $\left(\mathrm{V}_{1}\right)$ is the largest, so the energy consumption $\left(\mathrm{V}_{1}\right)$ is retained. Under ecological protection, the correlation coefficient among forest coverage rate $\left(\mathrm{V}_{4}\right)$, forest growing stock 
$\left(\mathrm{V}_{5}\right)$ and local fiscal expenditure on environmental protection $\left(\mathrm{V}_{6}\right)$ is less than the threshold value of 0.9 , so they are all retained. Under the environmental treatment, the correlation coefficient among total wastewater discharge $\left(\mathrm{V}_{11}\right)$, COD emission $\left(\mathrm{V}_{12}\right)$, ammonia nitrogen emission $\left(\mathrm{V}_{13}\right)$ and sulfur dioxide emission $\left(\mathrm{V}_{14}\right)$ is less than the threshold value of 0.9 , so they are all retained.

TABLE XVII. CORRELATION COEFFICIENT OF ECOLOGICAL INDICATORS

\begin{tabular}{|l|l|l|l|l|l|l|l|l|l|}
\hline & $\mathbf{V}_{\mathbf{1}}$ & $\mathbf{V}_{\mathbf{3}}$ & $\mathbf{V}_{\mathbf{4}}$ & $\mathbf{V}_{\mathbf{5}}$ & $\mathbf{V}_{\mathbf{6}}$ & $\mathbf{V}_{\mathbf{1 1}}$ & \multicolumn{1}{|c|}{$\mathbf{V}_{\mathbf{1 2}}$} & $\mathbf{V}_{\mathbf{1 3}}$ & $\mathbf{V}_{\mathbf{1 4}}$ \\
\hline $\mathrm{V}_{1}$ & 1.000 & 0.984 & -0.002 & 0.967 & 0.636 & 0.968 & 0.836 & 0.892 & 0.916 \\
\hline $\mathrm{V}_{3}$ & 0.984 & 1.000 & 0.061 & 0.994 & 0.557 & 0.945 & 0.839 & 0.935 & 0.906 \\
\hline $\mathrm{V}_{4}$ & -0.002 & 0.061 & 1.000 & 0.083 & 0.260 & 0.147 & -0.008 & -0.044 & -0.028 \\
\hline $\mathrm{V}_{5}$ & 0.967 & 0.994 & 0.083 & 1.000 & 0.531 & 0.912 & 0.824 & 0.927 & 0.889 \\
\hline $\mathrm{V}_{6}$ & 0.636 & 0.557 & 0.260 & 0.531 & 1.000 & 0.675 & 0.342 & 0.276 & 0.440 \\
\hline $\mathrm{V}_{11}$ & 0.968 & 0.945 & 0.147 & 0.912 & 0.675 & 1.000 & 0.825 & 0.851 & 0.894 \\
\hline $\mathrm{V}_{12}$ & 0.836 & 0.839 & -0.008 & 0.824 & 0.342 & 0.825 & 1.000 & 0.804 & 0.881 \\
\hline $\mathrm{V}_{13}$ & 0.892 & 0.935 & -0.044 & 0.927 & 0.276 & 0.851 & 0.804 & 1.000 & 0.820 \\
\hline $\mathrm{V}_{14}$ & 0.916 & 0.906 & -0.028 & 0.889 & 0.440 & 0.894 & 0.881 & 0.820 & 1.000 \\
\hline
\end{tabular}

Through principal component analysis and correlation analysis, energy consumption $\left(\mathrm{V}_{1}\right)$, forest coverage rate $\left(\mathrm{V}_{4}\right)$, forest growing volume $\left(\mathrm{V}_{5}\right)$, local fiscal environmental protection expenditure $\left(\mathrm{V}_{6}\right)$, total wastewater discharge $\left(\mathrm{V}_{11}\right)$, COD emission $\left(\mathrm{V}_{12}\right)$ ammonia nitrogen emission $\left(\mathrm{V}_{13}\right)$, and sulfur dioxide emission $\left(\mathrm{V}_{14}\right)$ are finally determined as ecological indicators (see "Table XVIII").

TABLE XVIII. ECOLOGICAL INDICATORS OF COORDINATED DEVELOPMENT EVALUATION IN BEIJING-TIANJIN-HEBEI REGION

\begin{tabular}{|c|c|c|c|}
\hline \multirow{2}{*}{ Dimension } & \multicolumn{2}{|r|}{ Indicator } & \multirow{2}{*}{ Unit } \\
\hline & First-level indicators & Secondary index & \\
\hline \multirow{8}{*}{ Ecology } & Resource consumption & Energy consumption & Ten thousand tons \\
\hline & \multirow{3}{*}{ Ecological protection } & Forest coverage rate & $\%$ \\
\hline & & Forest growing stock & Hundred million cubic meters \\
\hline & & $\begin{array}{l}\text { Local fiscal expenditure on environmental } \\
\text { protection }\end{array}$ & 100 million yuan \\
\hline & \multirow{4}{*}{$\begin{array}{l}\text { Environmental } \\
\text { governance }\end{array}$} & Discharge amount of wastewater & Ten thousand tons \\
\hline & & Chemical oxygen demand emissions & Ten thousand tons \\
\hline & & Sulfur dioxide emissions & Ton \\
\hline & & Ammonia nitrogen emissions & Ten thousand tons \\
\hline
\end{tabular}

According to "Table VI", "Table X", "Table XIV" and "Table XVIII", the evaluation indicator system of coordinated development in Beijing-Tianjin-Hebei region is finally determined.

\section{CONCLUSION}

Based on relevant literature, practical empirical exploration, and overall situation of the BeijingTianjin-Hebei national economy and social development, and from the multi-dimensional perspectives of science and technology, economy, society, and ecology, the coordinated development evaluation indicator system of the Beijing-TianjinHebei region is systematically designed. This indicator system can comprehensively reflect the differences in the development of different dimensions in the BeijingTianjin-Hebei region in different periods, make up for the lack of separate analysis of existing results from different dimensions, and better grasp the comprehensive problems in the development of the Beijing-Tianjin-Hebei region.

\section{References}

[1] Wang Bei, Liu Weidong, Lu Dadao. Allocation Efficiency of Science and Technology Resources in Jing-Jin-Ji, Yangtze River Delta and Pearl River Delta Regions [J]. Progress in Geography, 2011, 30(10): 1233-1239. (in Chinese)

[2] Xi Zenglei, Yuan Qingchuan, Xu Wei. Evaluation of the economic efficiency of scientific and technological innovation in the Beijing-Tianjin-Hebei region based on the MalmquistTFP model [J]. Macroeconomics, 2018(07): 132-140. (in Chinese)

[3] Sun Yukang, Li Guoping. Evaluation and upgrading of the Beijing-Tianjin-Hebei regional collaborative innovation capacity [J]. Progress in Geography, 2017, 36(01): 78-86. (in Chinese)

[4] Wang Cong, Zhu Xianqi, Liu Dinglin, Zhou Liqun. The Allocation Efficiency of S \& $\mathrm{T}$ Resource in Beijing-TianjinHebei Region under Regional Synergistic Innovation: A Two Stage Analysis of Super-efficiency [J]. SScience \& Technology Progress and Policy, 2017, 34(19): 47- 52. (in Chinese)

[5] Wu Fengqing, Gao Liyan, Chen Feiyu. Study on BeijingTianjin-Hebei Technology Gradient Measurement [J]. Enterprise Economy, 2013, 32(02): 171-176. (in Chinese)

[6] Yang Weizhong. The Research Group of the Business Management Department of the People's Bank of China. The Measurements of Urban Economic Gravity of China's Three 
Agglomerations and Its Enlightenment to the Collaborative Development of Beijing-Tianjin-Hebei Region [J]. Finance Forum, 2019, 24(04): 71-80. (in Chinese)

[7] Zhang Zhanbin. The Strategic Signifi cance of Synergy Development in Beijing-Tianjin-Hebei Region [J]. Environmental Protection, 2014, 17: 18-20. (in Chinese)

[8] Bo Wenguang, Chen Fei. The Coordinated Development among Beijing, Tianjin and Hebei: Challenges and Predicaments [J]. Nankai Journal (Philosophy and Social Sciences Edition), 2015(1): 110-118. (in Chinese)

[9] Sun Jiuwen.The goal, task and implementation path of the coordinated development of Beijing-Tianjin-Hebei [J]. Comparative Economic and Social Systems, 2016(3): 5-9. (in Chinese)

[10] Sun Jiuwen, Yao Peng. Industrial Relocation in Jing-Jin-Ji Region,Regional Specialization and Coordinated Development : An Analysis Based on the Framework of New Economic Geography [J]. Nankai Journal (Philosophy and Social Sciences Edition), 2015(1): 81-89. (in Chinese)

[11] Wei Lihua. Coordinated Development of Beijing, Tianjin and Hebei and its Features of Different Stages since the Founding of New China [J]. Journal of Shenzhen University (Humanities \& Social Sciences), 2016, 06: 143-150. (in Chinese)

[12] Chen Hong, Yang Liu. Research on Economic Integration of Beijing-Tianjin-Hebei Region [J]. Modern Management Science, 2016(09): 78-80. (in Chinese)

[13] Liu Hao, Ma Lin, Li Guoping. The spatiotemporal evolution of the unbalanced pattern of economic development in the BeijingTianjin-Hebei region since the 1990s[J]. Geographical Research, 2016, 35(03): 471-481. (in Chinese)

[14] Cheng Hui, Zhao Jianhua. The status quo, obstacles and breakthroughs of Beijing-Tianjin-Hebei regional economic integration [J]. People's Forum, 2014(29):95-97. (in Chinese)

[15] Guo Ping, Liu Guifen. Measurement of China's regional social undertaking development differences based on the perspective of synergy-Taking representative provinces in the three major regions as examples [J]. Huxiang Forum, 2014, 27(01): 58-63 . (in Chinese)

[16] Xie Yanzhi. Creating a new era of coordinated development of social work in Beijing, Tianjin and Hebei [J]. China Society, 2017(34): 18-19. (in Chinese)

[17] Zhou Bo, Zhang Wenling, Zhang Guodong, Yu Yi. Research on the Regional Integration of Social Security in Beijing, Tianjin and Hebei [J]. Knowledge Economy, 2017(24): 23. (in Chinese)

[18] Chen Zhiguo. The Research Group of the Macroeconomic Research Institute of Hebei Development and Reform Commission. Research on Promoting the Equalization of Basic Public Services in Beijing-Tianjin-Hebei [J]. Economic Research Reference, 2018(15): 55-64. (in Chinese)

[19] Wang Chunrui. Research on the Impact of Population Flow and Countermeasures under the Beijing-Tianjin-Hebei Coordinated Development Strategy [J]. Review of Economic Research, 2016 (64): 46-49. (in Chinese)

[20] Li Xu. Present Status, Problems and Strategies of Constructing the Regional College Alliance in Beijing-Tianjin-Hebei Area [J]. Journal of Higher Education, 2018, 39(06): 42-50. (in Chinese)

[21] Zheng Chen, Dong Wu. Research on the Emergency Linkage Mechanism of Beijing-Tianjin-Hebei Region under the Angle of Vulnerability [J]. Journal of Tianjin Administration Institute, 2018, 20(04): 36-42. (in Chinese)

[22] Tian Xuebin, Chen Yidan. The Feature Differentiation and Trend of Basic Public Services Equalization in Beijing-TianjinHebei [J]. Economy and Management, 2019, 33(06): 7-15. (in Chinese)
[23] Li Dong. Evaluation of Public Service Quality of Jing-Jin-Ji Region [J]. Areal Research and Development, 2018, 37(02): 52 57. (in Chinese)

[24] Wu Yiqing, Zhao Jianqiang. Measurement of Regional Basic Public Service Integration Level $[\mathrm{J}]$. Economy and Management, 2017, 31(04): 11-16. (in Chinese)

[25] Jiang Xi, Liu Yingying. Analysis on Equalization of Basic Public Services in Beijing, Tianjin and Hebei [J]. Business Economics Research, 2017(03): 211-213. (in Chinese)

[26] Lu Jitong. Equalization of Basic Public Services in Beijing Tianjin-Hebei: Crux Barriers and Countermeasures [J]. Sub National Fiscal Research, 2015(09): 70-75. (in Chinese)

[27] Yan Ye. On Integration Development of Jing-Jin-Ji Region and Social Governance of the Capital Region [J]. Journal of Shijiazhuang University, 2014, 16(05): 103-106. (in Chinese)

[28] Jia Shanshan, Yang Fei, Feng Zhenhuan. Assessment of the Vulnerability of Regional Social System-Taking the BeijingTianjin-Hebei Metropolitan Area as an Example [J]. Commercial Time, 2014 (32): 131-132. (in Chinese)

[29] Ba Qiqiang, Wang Lianfang. Ecological Environment Construction in Beijing, Tianjin and Hebei: Problems and Countermeasures [J]. Journal of Shijiazhuang Tiedao University (Social Science Edition), 2015, 9(04): 1-5. (in Chinese)

[30] Zhang Yu, Liu Moucheng, Bai Yanying, Zhang Yongxun. Application of ecological conservation cooperation for BeijngTianjin-Hebei regional integration [J]. Resources Science, 2015 37(08): 1529-1535. (in Chinese)

[31] Zhang Zhijiang. Ecological construction: the bottleneck of the coordinated development of Beijing-Tianjin-Hebei $[\mathrm{J}]$. Chinese Cadres Tribune, 2014(11): 69-71. (in Chinese)

[32] Qin Jing, Zhou Liqun, Jia Fengling. A Puzzle between Ecological Protection and Economic Development in the Background of Collaborative Development of Beijing, Tianjin and Hebei Province : Consideration Based on the Tianjin Ecological Red Line [J]. theory and moderization, 2015(05): 25 30. (in Chinese)

[33] Yu Ru, Cheng Jinhua. Evaluation of Regional Ecological Civilization Based on AHP-Fuzzy Model:A Study on the Pane Data of 13 Cities in Jing-Jin-Ji Region [J]. Areal Research and Development, 2019, 38(06): 11-15. (in Chinese)

[34] Meng Xue, Di Qianbin, Ji Jianwen. Measurement on the Level of the Urban Ecological Performance and Analysis of Influential Factors in Beijing-Tianjin-Hebei Urban Agglomeration [J]. Economic Geography, 2020, 40(01): 181186+225. (in Chinese) 